Original scientific article/Izvirni znanstveni članek

\title{
Organizational model of ensuring safety and quality of treatment of aggressive psychiatric patients in mental health nursing in Slovenia Organizacijski model zagotavljanja varnosti in kakovosti obravnave agresije pri pacientu $\mathrm{z}$ duševno motnjo v zdravstveni negi na področju psihiatrije v Sloveniji
}

\author{
Branko Gabrovec, Branko Lobnikar
}

\section{Key words: nursing; violence; psychiatric hospital \\ Ključne besede: zdravstvena nega; nasilje; psihiatrična bolnišnica \\ Branko Gabrovec, MSc, Grad. En. Log; Community Health Centre Celje, Gregorčičeva 5, 3000 Celje \\ Correspondence e-mail/ Kontaktni e-naslov: \\ branko.gabrovec@gmail.com \\ Associate Professor Branko Lobnikar, PhD; University of Maribor, Faculty of Criminal Justice and Security, Kotnikova ulica 8, 1000 Ljubljana.}

This article is based on the $\mathrm{PhD}$ thesis of Branko Gabrovec Organizational model of safety and quality assurance in psychiatric patient treatment in terms of diverse participants (2014).

\begin{abstract}
Introduction: The paper presents the organizational measures for managing violence in psychiatric settings and the study that introduces the preliminary success rate of the proposed model.

Methods: For the purpose of this study a non-experimental sampling method was employed using a structured questionnaire as a data collection instrument. The sample covered the personnel most frequently exposed to violence, namely, the nursing staff in closed and/or intensive psychiatric units in 5 Slovenian psychiatric hospitals, 3 psychiatric homes and 2 special education, and work and care centres. The data were statistically analysed with the SPSS 20 software package, with $p<0.05$ indicating statistical significance.

Results: The practical part of the functional training was conducted between 2010 and 2013 in specific psychiatric hospitals and wards. In a study carried out in 2013, preliminary results indicating the success rate of the proposed model were obtained.

Discussion and conclusion: Health care workers in psychiatry are responsible for providing safe and high quality treatment even in cases of aggressive outbursts, but they lack the necessary functional knowledge to cope with aggression in the workplace. The paper presents an organizational model for ensuring the safety of the patients and the quality of their treatment in case of an aggressive outburst, along with the presentation of the required functional training.
\end{abstract}

\section{IZVLEČEK}

Uvod: Članek predstavlja organizacijske ukrepe za upravljanje nasilja v psihiatričnih bolnišnicah in raziskavo, ki obravnava preliminarne rezultate predlaganega modela.

Metode: Izvedena je bila neeksperimentalna vzorčna metoda raziskovanja. Inštrument raziskave je bil strukturirani vprašalnik. Za izvedbo raziskave so bili izbrani nasilju najbolj izpostavljeni, tj. zaposleni v psihiatrični zdravstveni negi na intenzivnih in/ali zaprtih psihiatričnih oddelkih. $\mathrm{V}$ raziskavi je sodelovalo pet psihiatričnih bolnišnic, trije psihiatrični domovi in dva centra za usposabljanje, delo in varstvo. Podatki so bili obdelani s statističnim programom SPSS 20,0, upoštevana je bila stopnja značilnosti $p<0,05$.

Rezultati: Praktični del funkcionalnega izobraževanja se je izvajal v letih 2010-2013 v nekaterih psihiatričnih bolnišnicah in oddelkih. Preliminarna raziskava, ki je bila opravljena leta 2013, je pokazala na uspešnost predlaganega organizacijskega modela.

Diskusija in zaključek: Zaposleni v psihiatrični zdravstveni negi so odgovorni za zagotavljanje varnosti in kakovosti obravnave $\mathrm{v}$ primeru agresivnega izbruha, vendar za le-to ne posedujejo dovolj funkcionalnih znanj. Članek predstavlja organizacijski model za zagotavljanje varnosti in kakovosti obravnave v primeru agresivnega izbruha in ustrezno funkcionalno izobraževanje. 


\section{Introduction}

Despite its humanistic role, psychiatry, in contact with the environment, cannot avoid occasional violent behaviour of its patients. Psychiatrists at times attempt to ignore the potential as well as the actual violence, however, the general assertion that there is no violencefree psychiatry tends to remain valid (Kobal, 2009).

Ensuring the safety of psychiatric patients and the quality of their treatment is of paramount importance at every level of health care and of every medical profession. With the development of modern society and ensuing trends the incidence of psychiatric disorders is growing. Despite the advancement of psychiatry, violence and aggression remain a significant problem in psychiatric health settings. Therefore, acute psychoses and various other states where aggression is to be expected will continue to occur (Gabrovec, et al., 2014).

Groleger (2009) postulates that epidemiology of violent behaviour in psychiatry states that individuals with a mental illness behave violently 3-4 times more often than those in the control group. Prevalence of schizophrenia in the overall population is $1 \%$, among the perpetrators of criminal acts it reaches $3.6 \%$, among murderers 7-15\%, and among murderers who were acquitted due to insanity $57-80 \%$.

According to a Slovenian study as many as $42 \%$ of psychiatric nurses are exposed to physical violence and as many as $73 \%$ are of the opinion that more needs to be done in terms of security (Kolman, 2009). Health care workers, especially the nursing staff, are the occupational categories most frequently exposed to physical violence of psychiatric patients. However, other groups involved in the treatment process are also confronted with workplace violence as well: the police, security agencies, paramedics, personnel in retirement homes, and other. Between $35-80 \%$ of health care workers were at least once physically assaulted at their workplace, with nurses being the most exposed group (Clements, et al., 2005). The percentage of injuries in health care is 6.1 per 10,000 , while in other work fields it is 2.1 per 10,000 . Despite statistically high percentage of injured in health care, the actual numbers are even higher, mainly due to frequent non-reporting of incidents (Gates, et al., 2011). As many as $70 \%$ of incidents or abuses of nurses remain non-reported (Stokowski, 2010). A Swedish study shows that the majority of the participants $(85 \%)$ reported having been exposed to violence during their careers, with $57 \%$ being victimized in the past 12 months (Soares, 2000). Findings from a Swiss study reveals that $72 \%$ of nurses experienced verbal patient and visitor violence and $42 \%$ physical patient and visitor violence in the past 12 months. In addition, $23 \%$ were physically injured and $1.4 \%$ took one or more days of sick leave. Patient and visitor violence was distressing for the nursing staff (Hahn, et al., 2010). Medical staff in psychiatric hospitals and institutions are most frequently exposed to violent behaviour of patients. They are neither properly trained nor authorised to manage aggression. However, they are responsible for providing the safety of the aggressive and other patients, the physical surroundings and themselves. The nurses and the assistants who are in direct contact with patients are at the highest risk of being the victims of violence. Other hospital staff, paramedics and hospital safety officers are exposed to increased risk of violence as well (National Institute for Occupational Safety and Health, 2002). Among the most exposed are the workers in emergency medical units and especially those working in closed and intensive psychiatric wards. The number of (severe) violent incidents against staff by psychiatric inpatients is high (Van Leeuwen \& Harte, 2011). Nurses are the first to meet the victims of ever increasing violence. In addition, nurses suffer damage from social tolerance of violence (World Health Organization, 2002). Studies point to a varied but nevertheless high occurrence of all types of violence directed at nursing staff in psychiatric health care. In Taiwan $19.6 \%$ of nurses indicated that they had experienced physical violence (Pai \& Lee, 2011).

In 2013, an extensive study of incidence of violence against the employees in psychiatric hospitals, psychiatric homes, retirement homes and special education, work and care centres (SEWCC) was conducted in Slovenia (Gabrovec, et al., 2014). In Table 1 the types and percentage of violence against the employees in health care in Slovenian psychiatric hospitals are presented.

Table 1: Types and percentage of violence against the employees in health care in Slovenian psychiatric hospitals (Gabrovec, et al., 2014)

Tabela 1: Vrste in odstotki nasilja usmerjenega proti zaposlenim $v$ zdravstveni negi $v$ Slovenskih psihiatričnih bolnišnicah (Gabrovec, et al., 2014)

\begin{tabular}{lr}
\hline Types of violence/Vrste nasilja $(\boldsymbol{n}=\mathbf{2 0 3})$ & $\%$ \\
\hline Verbal abuse by patients & $92.6 \%$ \\
Verbal abuse by relatives & $40.9 \%$ \\
Verbal abuse by co-workers & $13.3 \%$ \\
Verbal abuse by superiors & $13.8 \%$ \\
Sexual harassment by patients & $24.6 \%$ \\
Sexual harassment by relatives & $0.5 \%$ \\
Sexual harassment by co-workers & $0.5 \%$ \\
Sexual harassment by superiors & $0.5 \%$ \\
Physical violence by patients & $84.2 \%$ \\
Physical violence by relatives & $2.0 \%$ \\
Physical violence by co-workers & $1.0 \%$ \\
Physical violence by superiors & $0.5 \%$ \\
Injury caused by patients & $63.5 \%$ \\
\hline
\end{tabular}

Legend/Legenda: $n$ - number/število; \% - percentage/odstotek 
The results of the study point to extensive exposure of employees to violence at workplace, especially by the patients. As many as $92.6 \%$ of all employees at psychiatric wards face verbal violence. These results are comparable only to those of a study conducted in Sweden (Soares, et al., 2000), where the percentage of physical violence by patients is $85 \%$ to Slovenian 84.2 $\%$, and to a Turkish study (Picakciefe, et al., 2012) with $71.4 \%$. The frequency of physical violence by patients in Slovenia is higher in comparison to $35-80 \%$ in the United States of America (USA) (Clements, et al., 2005), $25 \%$ in the USA (Privitera, et al., 2005), $42 \%$ in Switzerland (Hahn, et al., 2010). The findings of the study correspond to theory (Klemenc \& Pahor, 2000; Davison, 2005; Kobal, 2009), and the theories of violence in organizations (Pagon, et al., 2001; Bowie, 2002).

The study Gabrovec and colleagues (2014) further shows that the employees in psychiatric health care are equally threatened in the event of a violent outburst, regardless of their gender, age, work experience or level of education.

Health care workers require systematic and continuous aggressive situation management training (practical part) and general and institution specific management guidelines. The development of guidelines must include the cooperation between psychiatry and general martial arts approaches and principles, which is important for the preservation of a therapeutic relationship with the patient. The guidelines, as a general and an institution specific document should include all aspects of physical restraint, escort, therapy application, self-defence techniques and restraining with the belt. Instructions for physical restraint serve as a unified starting point for all personnel, procedures and the actual acts of physical restraint. The development of guidelines and continuous training contribute to medical workers' confidence and equip them with the knowledge to manage aggressive situations, which in turn leads to a more successful and safe management of such situations (Gabrovec, 2009).

\section{Organizational model for ensuring safety and quality of treatment in case of aggressive behaviour}

The proposed organizational model deals with comprehensive aggression management in patients with mental disorder. It sets theoretical frameworks of management and practical techniques when using special security measures and physical restraint. The model is the basis for functional education which rests mainly on practical training (Gabrovec, 2014).

Only a minority of health care workers (nurses, technicians, physicians, clinical psychologists) perceive their work as dangerous. The victims of patients' violent behaviour are most frequently nurses and health care technicians, especially in cases of involuntary hospitalization, physical restraint and the administration of medicaments (Gabrovec, 2014).

In their study Mrevlje and Umek (2011) showed that the respondents are of the opinion that more training in self-defence is needed, along with additional competent and predominantly male co-workers, communication skills training and better cooperation within the team. They also feel that health care workers, victims of patient's violent behaviour, should be entitled to some form of systematic help. Occasionally, violent events demand the intervention of the resident security service whose members are not adequately trained for such interventions. Therefore, these groups must be provided with training that will assist them in coping with aggression and violence at workplace.

The legal basis for the organizational model of ensuring safety against aggressive psychiatric patients is founded on the Slovenian Mental Health Act (2008), Recommendations and Guidelines for the Use of Special Measures in Psychiatry (Dernovšek \& Novak, 2001) and the Protocol for the Use of Physical Restraint in Hospitals (Kovač, 2012).

The organizational model is divided in to following modules:

- situation assessment and the identification of factors that increase the risk of aggressive behaviour;

- the use of behavioural cognitive and de-escalation techniques;

- the use of a special security measure;

- the use of adapted physical restraint techniques for managing aggression;

- measures following an aggressive outburst;

- education through functional training model (Gabrovec, 2014).

\section{Purpose and goal}

Employees in psychiatric health care are often confronted with the violence from patients with mental disorder. They are faced with various types of violence: verbal, sexual, physical violence often resulting in injuries. The paper introduces a model of functional education for the management of psychiatrics patients' aggressive behaviour, suitable for a wide range of involved participants who in their line of work encounter aggressive patient with mental disorder.

From 2010 to 2013 a pilot functional training programme in various psychiatric hospitals, wards, psychiatric homes and special education, work and care centres was carried out. In the form of workshops, the programme focused on the practical application of adapted techniques of physical restraint with the aim of managing aggressive behaviour. The aim of the study was to show:

- the extent of change of certain states and emotions of the employees following the functional education, and

- whether the knowledge of the employees has improved. 


\section{Hypotheses}

Hypothesis 1: There are statistically significant differences in identifying the competences and certain emotions obtained through training.

Hypothesis 2: There are statistically significant differences in dealing with the lack of knowledge before and after training.

Hypothesis 3: There are statistically significant differences in dealing with fear before and after training.

\section{Methods}

The empirical part of the study is based on the quantitative, non-experimental research, with a questionnaire being used as the method of gathering data.

\section{Description of the research instrument}

A structured questionnaire was used, designed on the basis of literature on both psychiatric conditions and ensuring security and quality of a psychiatric patient's treatment (Bowie, 2002; Davison, 2005; Kobal, 2009; Hahn, et al., 2010). The questionnaire consisted of 80 questions divided into five sets: work and workplace related violence, work management, the influence of various factors on patient safety and the quality of patient treatment, education and demographics. The dependent variable was risk management, while the independent variables were supplies sufficiency, a clear picture of risks involved, awareness of workrelated mistakes, attention to conditions that promote safety, attention to the importance of safety within the institution, reaction to outbursts of violence, supervision, motivation and personnel incentives, adequate number of employees, violent outbursts protocols, an unfortunate event report form, team treatment and support, improvement measures (introduced in this article). Following scales were utilised with descriptive scale (1 - 3): I don't agree, I partially agree, I agree.

While developing the questionnaire, a focus group of post graduate nursing students (2nd cycle) was formed whose remarks and suggestions were entered into the questionnaire.

The content of the questionnaire proved valid and reliable, with high enough degree of internal consistency (Cronbach Alpha minimum 0.82). The external validity of the questionnaire was evaluated through a focus group, prior to data acquisition.

\section{Sample description}

The most exposed employees were chosen to participate in the study: nursing staff in closed and/ or intensive psychiatric wards. 5 Slovenian psychiatric hospitals, 3 psychiatric homes and 2 special education, work and care centres participated in the study. The sample included male and female nursing employees with secondary, vocational, graduate, and postgraduate education, with varied years of work experience. The survey included the entire population of nursing employees (approximately 450) in intensive and/or closed wards of the aforementioned institutions.

386 questionnaires were distributed among the staff. $303(78.49 \%)$ returned and 83 did not return the questionnaire. The survey was conducted in March and April 2013.

Out of 303 participants, 117 (38.6\%) were male and $186(61.4 \%)$ were female. Mean age of the participants was 37.58 ( $s=8.9$ years). The oldest participant was 58 and the youngest was 19 years old. Their level of education was as follows: 206 (68 \%) secondary, 7 (2.3\%) vocational, $74(24.4 \%)$ graduate, $16(5.3 \%)$ postgraduate education. Their mean working experience was 15.97 $(s=9.3)$ years.

\section{Description of the research process and data processing}

The survey was conducted in March and April 2013. Participation in the survey was voluntary and the questionnaire was anonymous. A permission to conduct the survey was obtained from the management of each individual institution. The survey was conducted in accordance with the Code of Ethics for Nurses and Nurse Assistants of Slovenia and the Declaration of Helsinki. Written source analysis, descriptive statistics and certain other sophisticated statistical methods were used (e.g. Kruskal-Wallis test for comparing the results of individual test groups and the Mauchly's sphericity test). The data were statistically analysed with the SPSS 20 software package, with $p<0.05$ indicating statistical significance.

\section{Results}

In Table 2, some of the emotional competences and states experienced by the employees when treating an aggressive patient with mental disorder are presented (on a scale from 1 to 3 ).

The survey participants mostly have to cope with vulnerability (2.52), fear (2.49), insecurity (2.36), helplessness (2.03), lack of empathy by superiors (1.74), despair (1.77), lack of training (1.67), anger (1.64) and, to the smallest extent, with the lack of empathy by co-workers (1.34).

Out of 303 participants, 182 took part in the functional training programme. The degree to which their competences and emotional states have changed after the programme is shown in Table 3.

Survey participants state that all survey items have improved after the programme. The results indicate that Expertise (2.78), Assertiveness (2.74) and Organization 
Table 2: Employees dealing with certain emotions and states

Tabela 2: Soočanje zaposlenih $z$ določenimi stanji in čustvi

\begin{tabular}{|c|c|c|c|c|c|}
\hline Claim & $\begin{array}{l}\text { I don't } \\
\text { agree }\end{array}$ & $\begin{array}{c}\text { I partially } \\
\text { agree }\end{array}$ & I agree & $\bar{X}$ & $s$ \\
\hline Fear & $5.9 \%$ & $38.9 \%$ & $55.2 \%$ & 2.49 & 0.60 \\
\hline Insecurity & $12.3 \%$ & $38.4 \%$ & $49.3 \%$ & 2.36 & 0.69 \\
\hline Helplessness & $21.2 \%$ & $53.7 \%$ & $25.1 \%$ & 2.03 & 0.68 \\
\hline Lack of training & $48.3 \%$ & $36.5 \%$ & $15.3 \%$ & 1.67 & 0.72 \\
\hline Anger & $47.8 \%$ & $40.4 \%$ & $11.8 \%$ & 1.64 & 0.68 \\
\hline Despair & $49.3 \%$ & $23.6 \%$ & $27.1 \%$ & 1.77 & 0.84 \\
\hline Vulnerability & $6.9 \%$ & $34 \%$ & $59.1 \%$ & 2.52 & 0.62 \\
\hline Lack of empathy by co-workers & $70 \%$ & $25.1 \%$ & $4.9 \%$ & 1.34 & 0.57 \\
\hline Lack of empathy by superiors & $42.9 \%$ & $39.4 \%$ & $17.7 \%$ & 1.74 & 0.73 \\
\hline
\end{tabular}

Legend/Legenda: $\bar{x}$ - average/povprečje; s-standard deviation/standardni odklon

Table 3: Identification of competences and emotional states gained through the programme Tabela 3: Identifikacija kompetenc in čustev, pridobljenih z izobraževanjem

\begin{tabular}{lccccc}
\hline & $\boldsymbol{n}$ & Min & Max & $\overline{\boldsymbol{X}}$ & $\boldsymbol{s}$ \\
\hline Organization & 182 & 1.00 & 3.00 & 2.68 & 0.54 \\
Expertise/professionalism & 182 & 1.00 & 3.00 & 2.78 & 0.43 \\
Assertiveness & 182 & 1.00 & 3.00 & 2.74 & 0.48 \\
Proactivity & 182 & 1.00 & 3.00 & 2.63 & 0.49 \\
Self-confidence & 182 & 1.00 & 3.00 & 2.67 & 0.51 \\
Fear & 182 & 1.00 & 3.00 & 2.11 & 0.73 \\
Helplessness & 182 & 1.00 & 3.00 & 2.28 & 0.70 \\
Insecurity & 182 & 1.00 & 3.00 & 2.48 & 0.66 \\
Lack of training & 183 & 1.00 & 3.00 & 2.57 & \\
Valid N & 182 & & & & \\
\hline
\end{tabular}

Legend/Legenda: $n$ - number/število; Min - minimum/minimum; Max - maximum/maksimum; $\bar{x}$ - average/povprečje; $s$ - standard deviation/standardni odklon

Table 4: Descriptive statistics of the »lack of expertise " variable (before and after the programme) Tabela 4: Opisne statistike spremenljivke neznanje (pred in po usposabljanju)

\begin{tabular}{|c|c|c|c|c|}
\hline & Institution/Organizacija & $\bar{X}$ & $s$ & $n$ \\
\hline \multirow{4}{*}{$\begin{array}{l}\text { Lack of expertise } \\
\text { (before programme) }\end{array}$} & Psychiatric hospital & 1.69 & 0.72 & 146 \\
\hline & Psychiatric homes, retirement homes & 1.46 & 0.70 & 26 \\
\hline & SEWCC & 1.36 & 0.50 & 11 \\
\hline & All & 1.64 & 0.71 & 183 \\
\hline \multirow{4}{*}{$\begin{array}{l}\text { Lack of expertise } \\
\text { (after the programme) }\end{array}$} & Psychiatric hospital & 2.64 & 0.62 & 146 \\
\hline & Psychiatric homes, retirement homes & 2.26 & 0.72 & 26 \\
\hline & SEWCC & 2.45 & 0.82 & 11 \\
\hline & All & 2.57 & 0.66 & 183 \\
\hline
\end{tabular}

Legend/Legenda: $\bar{x}$ - average/povprečje; $s$ - standard deviation/standardni odklon; $n-$ number/število

(2.68) bettered to the greatest extent and Fear (2.11) and Helplessness (2.28) to the smallest extent. Other items were graded: Self-confidence (2.67), Proactivity (2.63), Lack of training (2.57) and Insecurity (2.48). The best rated item 'Expertise' points to a high added value of the programme, whereas the worst rated 'Fear' to the need of including fear management to the proposed organizational model, thereby confirming Hypothesis 1. The variable 'Fear' was also cross-checked with the use of Wilcoxon Signed-rank test, which confirmed that no statistically important differences occurred prior or after the programme with most of the survey 
Table 5: 'Lack of expertise' variable effect testing within the groups

Tabela 5: Testiranje učinkov znotraj skupin pri spremenljivki neznanje

\begin{tabular}{|c|c|c|c|c|c|c|c|}
\hline Source & & $\begin{array}{l}\text { Type III } \\
\text { Sum of } \\
\text { Squares }\end{array}$ & df & $\begin{array}{l}\text { Mean } \\
\text { Square }\end{array}$ & $F$ & $p$ & $\begin{array}{c}\text { Partial } \\
\text { Eta } \\
\text { Squared } \\
\end{array}$ \\
\hline \multirow{4}{*}{$\begin{array}{l}\text { Lack of } \\
\text { expertise }\end{array}$} & Sphericity Assumed & 29.68 & 1 & 29.68 & 76.05 & $<0.001$ & 0.29 \\
\hline & Greenhouse-Geisser & 29.68 & 1 & 29.68 & 76.05 & $<0.001$ & 0.29 \\
\hline & Huynh-Feldt & 29.68 & 1 & 29.68 & 76.05 & $<0.001$ & 0.29 \\
\hline & Lower-bound & 29.68 & 1 & 29.68 & 76.05 & $<0.001$ & 0.29 \\
\hline \multirow{4}{*}{$\begin{array}{l}\text { Lack of } \\
\text { expertise }\end{array}$} & Sphericity Assumed & 0.35 & 2 & 0.17 & 0.45 & 0.63 & 0.005 \\
\hline & Greenhouse-Geisser & 0.35 & 2 & 0.17 & 0.45 & 0.63 & 0.005 \\
\hline & Huynh-Feldt & 0.35 & 2 & 0.17 & 0.45 & 0.63 & 0.005 \\
\hline & Lower-bound & 0.35 & 2 & 0.17 & 0.45 & 0.63 & 0.005 \\
\hline \multirow{4}{*}{$\begin{array}{l}\text { Error } \\
\text { Lack of } \\
\text { expertise }\end{array}$} & Sphericity Assumed & 70.25 & 180 & 0.39 & & & \\
\hline & Greenhouse-Geisser & 70.25 & 180.00 & 0.39 & & & \\
\hline & Huynh-Feldt & 70.25 & 180.00 & 0.39 & & & \\
\hline & Lower-bound & 70.25 & 180.00 & 0.39 & & & \\
\hline
\end{tabular}

Legend/Legenda: $d f$ - mean value of sum squares/povprečje vsote kvadratov: Sig - p value/vrednost p; F statistic - fixation indices/F statistika

participants. Table 4 demonstrates the descriptive statistics of the 'lack of expertise' variable (before and after the programme).

The survey results show that the mean value of the 'Lack of expertise' before the programme was 1.65 , whereas after the programme it rose up to 2.58 . However, when looking at the estimate of the 'Lack of expertise' according to the institution, the perception of the 'Lack of expertise' after the programme diminished in all types of institutions.

The study also shows that the estimated mean value of the perception of the 'Lack of expertise' in the period before and after the programme increased. Table 5 demonstrates 'Lack of expertise' variable effect testing within the groups.

The study shows that the sphericity was not achieved. Consequently, the Greenhouse-Geisser line in the table indicates that in overall, there are statistically significant differences between the studied periods in the perception of the lack of expertise $(F=76.05$, $p<0.001, p<0.05)$. Thereby, hypothesis 2 is confirmed. The study validated the preliminary successfulness of the proposed organizational model. The results were additionally tested from the point of view of demographic data and the type of institution as related to the lack of expertise and proficiency, whereby no significant statistical differences were established $(F=0.45$, $p<0.63, p<0.05$ ).

The emotion of fear before and after the training was also examined.

The study shows that the fear medians remained the same before and after training. The feelings of fear were measured on a scale of 1 to 3 , with 1 indicating disagreement, 2 partial agreement and 3 complete agreement with the statement that the feeling of fear occurs during the treatment of a patient.
Wilcoxon Signed-Rank test was performed in order to determine the difference between the feeling of fear before and after training. The test points to statistically significant differences in perceiving fear before and after training $(z=-3.569, p<0.05)$.

The study indicates that no changes occurred in 76 employees, 67 felt a change for the better and 37 felt a change for the worse. The medians before and after training were the same, therefore hypothesis 3 was rejected since it held true for most of the participants that there were no statistically significant changes in the perception of fear. A possible explanation for this occurrence was the short duration of the training programme at the time of the survey.

\section{Discussion}

The results of this study point to extensive exposure of employees to violence at workplace, especially by the patients. Compared to the rest of the world, the results are only comparable with a study conducted in Sweden (Soares, et al., 2000) and to a Turkish study (Picakciefe, et al., 2012). The frequency of physical violence by patients is higher in Slovenia in comparison to the USA (Clements, et al., 2005; Privitera, et al., 2005) and Switzerland (Hahn, et al., 2010).

The results also indicate that respondents predominantly have to cope with vulnerability, fear, insecurity, helplessness, lack of empathy by superiors, despair, lack of training, anger and, to the smallest extent, with the lack of empathy by co-workers.

From 2010 to 2013 a pilot functional training programme in various psychiatric hospitals, wards, psychiatric homes and special education, work and care centres was carried out. In the form of workshops, the programme focused on the practical application of 
adapted techniques of physical restraint with the aim of managing aggressive behaviour. In view of the short duration of the training programme, the primary aim was to obtain preliminary data on the successfulness of the programme.

Survey participants state that all survey items have improved after the programme: Expertise, Assertiveness and Organization to the greatest extent, and Fear and Helplessness to the smallest extent. The best rated item 'Expertise' points to a high added value of the programme, whereas the worst rated 'Fear' to the need of including fear management to the proposed organizational model. The study indicates no statistically significant changes in the perception of fear in most of the participants, most probably due to the short duration of the training programme at the time of the survey.

The findings of the current study on the prevalence of violence directed at employees in psychiatric health care are consistent with those of other studies. Since no similar research has as yet been conducted on the success rate of the proposed model in other countries, no direct comparison is presently possible. Preliminary results on the successfulness of the training programme indicate its positive influence on the effectiveness of their work and the security of the employees and in turn the patients. Therefore, it would be reasonable to use this form of training in all institutions where psychiatric patients' violence occurs.

\section{Limitations of the study}

In terms of methodology, the study is deficient because it was not conducted in our largest psychiatric hospital. However, it did include all the others (6). Since it encompassed the entire employee population in intensive wards, the results can be generalized. Deficiencies can be further ascertained in the measurement scale in certain questions where the scale was 1 to 3 and not 1 to 5 , which would facilitate greater data dispersion and easier data analysis.

\section{Conclusion}

The paper discusses the incidence of aggression in psychiatric health care settings in Slovenia. The epidemiological, experiential and empirical data of the frequency of aggression directed towards the employees in psychiatric health care facilities are presented. The purpose and objective of the research were achieved.

An organizational model for ensuring safety and quality of treatment in case of an aggressive patient with mental disorder and preliminary results of the success rate of the functional training based on the proposed model are examined. The results lead to a conclusion that the organizational model is suitable for wider use with all stakeholders involved in the treatment of a patient with mental disorder and for the development of a health care standard and manual. The implementation of the training programme is recommendable also in other institutions encountering psychiatric patients' violence. Repeated research is advised in order to clearly determine whether the programme may bring about the intended or expected effect. Further studies are reasonable in somatic medicine, which would enable the development of a model of training for other medical professionals and the implementation of a special security measure.

\section{Acknowledgment}

We would like to thank the health care and nursing management, and nursing employees for participating in the study.

\section{Literature}

Bowie, V., 2002. Defining violence at work: a new typology. In: Gill, M., Fisher, B. \& Bowie, V. eds. Violence at work: couses, patterns and prevention. Portland: Willan Publishing. pp.1-20.

Clements, P.T., DeRanieri, J.T., Clark, K., Manno, M.S. \& Kuhn, D.W., 2005. Workplace violence and corporate policy for health care settings. Nursing Economics, 23(3), pp. 119-124. PMid:16033140

Davison, S.E., 2005. The management of violence in general psychiatry. Advances in Psychiatric Treatment, 11, pp. 362-370. http://dx.doi.org/10.1192/apt.11.5.362

Dernovšek, M. \& Novak, G.V., 2001. Priporočila in smernice za uporabo posebnih ukrepov v psihiatriji. Ljubljana: Viceversa.

Gabrovec, B., 2009. Smernice fizičnega oviranja. In: Poček, U. ed. Nasilno vedenje $v$ duhu novih praks: smernice fizičnega oviranja. Ljubljana: Zbornica zdravstvene in babiške nege - Zveza strokovnih društev medicinskih sester, babic in zdravstvenih tehnikov Slovenije, Sekcija medicinskih sester in zdravstvenih tehnikov v psihiatriji, pp. 25-26.

Gabrovec, B., Eržen, I. \& Lobnikar, B., 2014. The prevalence and the nature of violence directed at the medical staff in psychiatric health care in Slovenia. HealthMED, 8(2), pp. 228-234.

Gabrovec, B., 2014. Organizacijski model zagotavljanja varnosti in kakovosti obravnave psihiatričnega bolnika $z$ vidika različnih deležnikov: doktorska disertacija. Kranj. Univerza v Mariboru, Fakulteta za organizacijske vede, p.122.

Gates, D.M, Gillespie, G.L, \& Succop, P., 2011. Violence against nurses and its impact on stress and productivity. Nursing Economics, 29(2), pp. 59-67.

PMid:21667672 
Groleger, U., 2009. Agresivnost. In: Pregelj, P. \& Kobentar, R. eds. Zdravstvena nega in zdravljenje motenj $v$ duševnem zdravju. Ljubljana: Rokus Klett, pp. 288-294.

Hahn, S., Muller, M., Needham, I., Dassen, T., Kok, G., \& Halfens, R.J.G., 2010. Factors associated with patient and visitors violence experienced by nurses in general hospitals in Switzerland: a cross-sectional survey. Journal of Clinical Nursing, 19(23-24), pp. 3535-3546.

http://dx.doi.org/10.1111/j.1365-2702.2010.03361.x

PMid:20958803

Kobal M., 2009. Security and legal psychopathology. Ljubljana: University of Maribor, Faculty of Criminal Justice and Security.

Kolman, K., 2009. Ogroženost medicinskih sester in zdravstvenih tehnikov v psihiatrični bolnišnici: diplomsko delo visokošolskega študija. Ljubljana: Univerza v Mariboru, Fakulteta za varnostne vede.

Kovač, P., 2012. Physical restraint of pacients in clinical practice. In: Bregar, B. \& Peterka-Novak, J. eds. Restraint and seclusion as special precautionary measures in theory and clinical settings: proceedings of lectures with peer review. Ljubljana: Zbornica zdravstvene in babiške nege - Zveza strokovnih društev medicinskih sester, babic in zdravstvenih tehnikov Slovenije, Sekcija medicinskih sester in zdravstvenih tehnikov v psihiatriji, pp. 5-12.

Klemenc, D. \& Pahor, M., 2000. Nasilje na delovnih mestih medicinskih sester v Sloveniji. In: Klemenc, D. \& Pahor M. eds. Nasilje in spolno nadlegovanje na delovnih mestih medicinskih sester $v$ Sloveniji. Ljubljana: Društvo medicinskih sester in zdravstvenih tehnikov, pp. 12-35.

Mrevlje, P.T. \& Umek, P., 2011. Safety issues in psychiatric settings. Varstvoslovje, Journal of Criminal Justice and Security, 13(4), pp. 431-443. Available at: http://www.fvv.uni-mb.si/rV/ arhiv/2011-4/06 PavsicMrevlje Umek.pdf [16.11.2014].

National Institute for Occupational Safety and Health, 2002. Violence occupational hazards in hospitals. Atlanta: Centers for Disease Control and Prevention. Available at: http://www.cdc.gov/niosh/docs/2002-101/ [5. 6. 2014].
Pagon, M., Lobnikar, B. \& Jereb, J., 2001. Agresivno vedenje in nasilje na delovnem mestu ter pomen njunega upravljanja za zagotavljanje organizacijske uspešnosti in učinkovitosti. In: Vukovič, G. ed. Management in globalizacija: zbornik posvetovanja $z$ mednarodno udeležbo. Kranj: Moderna organizacija, pp. 114-127.

Pai, H.C, \& Lee, S., 2011. Risk factors for workplace violence in clinical registered nurses in Taiwan. Journal of Clinical Nursing, 20(9-10), pp. 1405-1412.

http://dx.doi.org/10.1111/j.1365-2702.2010.03650.x

PMid:21492284

Picakciefe, M., Akca, S., Elibol, A., Deveci, A., Yilmaz, N. \& Yilmaz, U.E., 2012. The analysis of violence against the nurses who are in employee status in Mugla State Hospital, Turkey. HealthMED, 6(11), pp. 3626-3637.

Privitera, M., Weisman, R., Cerulli, C. Tu, X., \& Groman, A., 2005. Violence toward mental health staff and safety in the work environment. Occupational Medicine, 55(6), pp. 480-486. http://dx.doi.org/10.1093/occmed/kqi110

PMid:15923198

Stokowski, L.A., 2010. Violence: not in my job description. Workplace Violence in Healthcare Settings. Available at: http://www.medscape.com/viewarticle/727144 [5. 6. 2014].

Soares, J.J.F., Lawoko, S. \& Nolan, P., 2000. The nature, extent and determinants of violence against psychiatric personnel. Work and Stress, 14(2), pp. 105-120.

http://dx.doi.org/10.1080/026783700750051630

Van Leeuwen, M.E, \& Harte, J.M., 2011. Violence against care workers in psychiatry: is prosecution justified? International Journal of Law and Psychiatry, 34(5), pp. 317-323.

http://dx.doi.org/10.1016/j.ijlp.2011.08.011

PMid:21924773

World Health Organization, 2002. World report on violence and health. Geneva: WHO.

Zakon o duševnem zdravju, 2008. Uradni list Republike Slovenije št. $77 / 2008$

Cite as/Citirajte kot:

Gabrovec, B. \& Lobnikar, B., 2014. Organizational model of ensuring safety and quality of treatment of agressive psychiatric patients in psychiatric health care in Slovenia. Obzornik zdravstvene nege, 48(4), pp. 286-293. http://dx.doi.org/10.14528/snr.2014.48.4.33 